\title{
Elena Gulicheva
}

National Research University "Moscow Power Engineering Institute", Moscow, Russian Federation

Email:gulichevayg@mpei.ru

\section{Evgeny Lisin}

National Research University "Moscow Power Engineering Institute", Moscow, Russian Federation

Email: lisinym@mpei.m

\section{Marina Osipova}

National Research University "Moscow Power Engineering Institute", Moscow, Russian Federation

Email: osipovams@mpei.ru

\author{
Asset Khabdullin \\ Rudny Industrial Institute, \\ Rudny, Kazakhstan \\ Email: aset85@mail.ru
}

Abstract. The article considers the problem of forming innovative education environment at the universities along with the problem of ensuring long-term competitiveness of education services at both national and global markets. The management model of an innovative education environment is offered, with particular attention being paid to the development of innovative technologies of global education as well as education services' export. Based on the statistical study of the dynamics in the number and composition of foreign students studying in Russia along with a comparative analysis of education costs at the

Received: October, 2016 1st Revision: March, 2017

Accepted: May, 2017

DOI: $10.14254 / 2071$ $8330.2017 / 10-2 / 9$ universities-leaders of academic mobility, a forecast is presented concerning the development of the export of Russian universities' knowledge while shaping the innovative education environment inside the country.

Keywords: innovative education, educational environment, internationalization, innovations, global education, export of educational services.

JEL Classification: I20, I23, I25 


\section{INTRODUCTION.A PROJECT: DEFINITION AND CHARACTERISTICS}

Creation and development of innovative education environment at the university is aimed at solving the strategic tasks of staffing process for further production and mastering of technological and managerial innovations that contribute to increasing the competitiveness of the country in the world economic space, and setting the priorities in national long-term policies.

Establishment of innovative economy in the world leading countries as a form of post-industrial development, which main source of social production is information and knowledge, has led to the prioritization of intellectual workers and their training. The most valuable qualities of such a worker have become the level of education, professionalism, learning ability and creativity (Č́ablková \& Strielkowski, 2013). Requirements as to the level, flexibility, availability of education systems have increased significantly (Gardelle et al., 2017).

In order to meet the listed requirements for the system of training, universities have started to pay much attention to the development of continuous and distance education. The key challenge is to ensure access to life-long education for all people. First of all, this applies to the postgraduate forms of training.

At the same time, economic globalization and formation of a unified labor market have led to standardization of higher education worldwide. Convergence and harmonization of the world education systems contribute to the development of science and education through the implementation of students and graduate mobility programs, and staff development (Healey, 2017). The process of recognition of training programs by national universities ensures that qualifications of specialists are consistent with the current requirements of the labor market.

Globalization of the economy in all its spheres (e.g. energy, science, education etc.) has led to the increased competition at the education services market (Balitskiy et al., 2014; Abrhám et al., 2015). Universities need to develop innovative approaches to global education so that to provide the necessary degree of competitiveness. It is vital to offer a broad basic education with a large number of opportunities, such as double diplomas, double degrees, and joint diplomas with a set of courses associated with the specialty's core. Training should be based on the organized research, and higher education should encourage students get engaged in research and inventions.

Innovative education environment enables universities provide long-term competitiveness of education services through elaboration of competitive resources and development of innovative approaches and methods of global education.

\section{INTERNATIONALIZATION OF HIGHER EDUCATION AS A FACTOR OF CREATING AN INNOVATIVE EDUCATIONAL ENVIRONMENT AT RUSSIAN UNIVERSITIES}

One of the global processes of higher education development is the internationalization of universities. The internationalization of the higher education system promotes the intensification of both the sphere of educational services and economic activity of the countries of higher education institutions.

The process of internationalizing education at the global level is managed by international institutions and organizations such as the United Nations, OECD, World Bank under UNESCO management (Table 1).

Under the current conditions (Stukalova et al., 2015), the formation of an innovative educational environment of the university is a consequence of the growing international competition in the market of educational services (export-import of knowledge), and relies on general and specific working conditions of the university under the influence of state stimulation of its educational activity. 
Levels of the management process of educational activities internationalization

\begin{tabular}{|l|c|c|c|}
\hline \multicolumn{1}{|c|}{ Levels } & Subjects & Processes & Driving Force \\
\hline Global & UNESCO & Globalization of the educational & $\begin{array}{c}\text { Globalization of the } \\
\text { world processes }\end{array}$ \\
\hline National & National & $\begin{array}{c}\text { Integration of National } \\
\text { Educational Systems }\end{array}$ & \\
\cline { 1 - 3 } Institutional & Universities & $\begin{array}{c}\text { Internationalization of all spheres } \\
\text { of university activity }\end{array}$ & \\
\hline
\end{tabular}

Source: Own results

Innovative development of universities helps to increase their level of competitiveness on the market of educational services, as well as to ensure financial stability both through the work volume and the transition to new standards of quality of the process of obtaining knowledge and the quality of knowledge itself (Pukhova et al., 2016). It also helps to create and foster innovativeness in further applications (Ehrenberger et al., 2015; Koudelková et al., 2015).

Figure 1 shows the innovative educational environment of the Russian university, describing the conditions for its functioning and development. These conditions are determined by the personnel of the university, the demands of the consumers of educational services, material-technical and informational support of the educational process, the student environment, the structure and availability of financial sources, in particular, grant financing. The innovative educational environment of the university is influenced by many factors: from the political-economic to the private-social ones.

The human (staff) potential of the university forms the core of an innovative educational environment, around which all the material and technical resources and other resources necessary for the training of specialists come into motion (Blanchard \& Olney, 2017). An important role in the work of the teaching staff and in the growth of the qualifications is played by the system of remuneration (wages, bonuses and grant financing). For Russian universities, this system is one of the major problems that require a solution. Its imperfection does not allow Russian universities to properly preserve and develop their human resources (Ivanova \& Popova, 2017).

The active international work of the university also has a significant impact on improving the quality of education. Interaction of the universities of different countries in the framework of joint scientificpractical conferences, exchange of opinions and scientific information, conclusion of international agreements and memorandums, the development of curricula contributes to the formation of training programs for the global economy, characterized by high demands on the quality of human resources.

The innovative educational environment of the university is based on the material - technical and informational support of the educational process, promoting the introduction of new progressive educational technologies. Material and technical support for the learning process serves as a guarantee of the stability of these processes and improvement of the knowledge quality.

Scientific activity is the foundation of a modern university. One can say that the formation of the university starts precisely from the organization of this process. In the future, scientific activity will determine the scale and dynamics of the university's growth, promotes the development of human resources and the quality of training the specialists.

The tasks the university is facing have a general orientation and serve the interests of consumers of educational services who are meant to be the recipients of the higher educational institution functioning. Among consumers of educational services, it is worth mentioning the entrants, students, graduates of the 
university, foreign specialists, whose training and advanced training are being conducted for foreign countries. Any assessment of the university's activities, its rating and image is based on the level of knowledge of graduates, reflecting the result of the education system functioning.

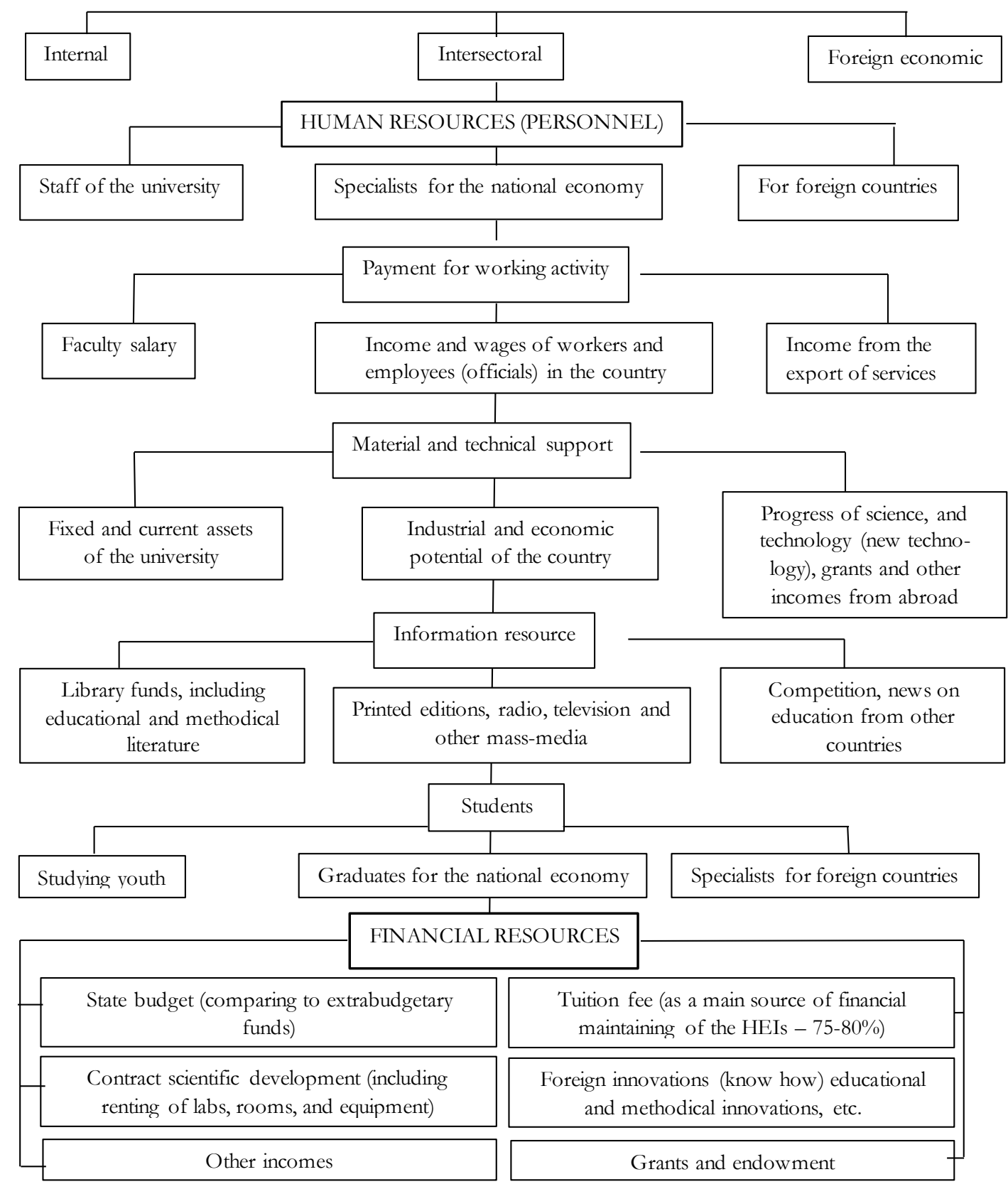

Figure 1. Innovative educational environment of the university

Source: Own results

In a market economy, the scientific and educational activities of the university require constant financial resources, created both at the expense of the state budget and at the expense of entrepreneurial activity. The entrepreneurial model of the university functioning involves the use of such sources of financing as paid educational services, programs of improvement of professional skills, inter-governmental research, 
commercialization of the results of scientific and technical research and development. Concerning the internationalization of higher education at Russian universities, such forms of attraction of financial resources as sponsorship, patronage, foreign grants and endowment are being developed.

\section{INNOVATIVE TECHNOLOGIES OF GLOBAL EDUCATION}

Global education becomes interdisciplinary. In the process of training specialists there is a close connection between technical, social and human sciences. The goal is to learn throughout life.

One of the key technologies of global education that will shape the future of educational systems and educational requirements is Life-Long Learning, which addresses the goal of making lifelong learning accessible to people (Noskova et al., 2016).

Another innovative technology of global education is distance learning, which is characterized by the term "E-learning" in Russian and foreign practice. Today, the task of universities is to make postgraduate education available at any time in any place of the world in the shortest possible time.

The organization of learning based on this approach allows to:

- reduce the cost of training by $30-40 \%$;

- reduce teaching time by at least $20 \%$;

- improve the quality of education.

The demand for a distance learning form (Lytvyn et al., 2016) reflects the real demand of the economy. The development of a distance learning form allows universities to gain international recognition and increase the number of students with full tuition fees. At the same time, the distance learning form allows to move the training process to production or home conditions, thus allowing enterprises to improve the quality of the workforce without interrupting employees from the main production process.

Another technology of global education is the creation of open electronic educational resources. This technology appeared as a result of comprehensive informatization of educational activities.

There are two approaches to creating educational resources.

An example of the first approach is the project of the Massachusetts Institute of Technology (Open Course Ware), where all the curriculum and university courses are openly accessible. They can be used for studying the course individually or organizing the educational process. At the same time it is prohibited to change the content of the course and supplement it. Thus, the expansion of the educational system of the university, together with the technology of organizing the educational process, is being implemented.

An example of the second approach is the Connexions project. The information is presented in the form of modules in the project. The user of the modules forms courses into disciplines, training manuals and other teaching materials. This project is essentially a depository that can be used by the users to achieve educational goals using their own learning organization technology.

The technology of global education, which combines the efforts of several universities, is the implementation of dual diploma programs. The general meaning of such programs is that universities agree on the recognition of a part of the curriculum, on the basis of which students can receive a second diploma in the shortest possible time. As the educational process takes place in several universities with different approaches to educational activities, a graduate program of the dual diploma will be much better prepared for working in the global economy (Shvetsova, 2016; Voroshilova, 2015). The program of double diploma requires the coordination of curricula and bringing the disciplines in line with international requirements, which increases the quality of education and determines the competitiveness of curricula.

The high cost of double-diploma programs has led to the development of electronic campus technology, which allows students to study the disciplines of the university-partner in a distance form. The 
system of electronic campus allows organizing access to the university's educational resources and building an educational process in accordance with the curriculum.

Investing in information technology is the highest priority in the plans for the development of innovative educational environment of leading universities. Thanks to the global information networks, students are no longer isolated. Modern education is built on the basis of information technology, the organization of technological infrastructure and the development of content and opportunities for working with electronic educational resources. Access to educational programs and resources is carried out through information technology, the application of which is described by an appropriate methodology that determines the technology of learning.

\section{THE PROBLEM OF EXPORTING KNOWLEDGE}

Knowledge export is the basis of the innovative development of education at the university under the current conditions of the development of the market for educational services and the economy globalization.

At the same time, it should be noted that despite the rapid development of communication and information technologies, the main way of "transferring" educational services across borders is to move students and teachers. This process of international exchange of "bearers" of knowledge is called international academic mobility. Throughout its history, the international academic mobility has contributed to the development of higher education (Shakirova \& Valeeva, 2016).

The evidence of ever-changing innovation environment of the university and the impact on its export of educational services is the increase in the share of foreign citizens in the total number of students (Table 1).

Table 1

The dynamics of total number of foreign students studying in the Russian Federation

\begin{tabular}{|l|c|c|c|}
\hline Years & $\begin{array}{c}\text { Number of students, } \\
\text { thousands }\end{array}$ & $\begin{array}{c}\text { Foreign students, } \\
\text { thousands }\end{array}$ & $\begin{array}{c}\text { Share of foreign students in } \\
\text { total number of students, \% }\end{array}$ \\
\hline $2009 / 2010$ & 7419 & 145,9 & 2,3 \\
\hline $2010 / 2011$ & 7050 & 153,8 & 2,2 \\
\hline $2011-2012$ & 6499 & 158,4 & 2,4 \\
\hline $2012 / 2013$ & 6075 & 165,9 & 2,7 \\
\hline $2013 / 2014$ & 5647 & 205,7 & 3,6 \\
\hline Growth, $\%$ & 76,1 & 141,0 & 156,5 \\
\hline
\end{tabular}

Over the last 5 years, the number of students of Russian universities has decreased by almost a quarter, which may be explained by the demographic situation and the decrease in the number of high school graduates (Gurban \& Tarasyev, 2016). At the same time, the number of foreign students studying at Russian universities has increased significantly (by more than 40\%). Their ratio to the total number of students has increased by 1.5 times and is estimated at 3.6\% (Kupriyanov \& Gorodetskaya, 2015).

The total volume of exports of educational services in the country is largely determined by the cost of training. Table 2 shows that the highest cost of tuition comes from the leading US universities (31,456 US dollars), Great Britain (24,748US dollars), and Australia (20,164 US dollars). The minimum training costs have Malaysian universities (1,464-1,704 US dollars). The average cost of education is typical for New Zealand, Singapore, and Canada. Russia in the range of these indicators is below the average, which is a 
competitive advantage in the field of export of educational services while respecting the required quality of training (Sosnovskaya \& Nalimova, 2016).

Table 2

Comparative costs for study at the higher educational institutions of countries-leaders of academic student mobility

\begin{tabular}{|c|c|c|c|}
\hline Countries & Universities & Curricula & $\begin{array}{l}\text { Averaged } \\
\text { tuition fee, US } \\
\text { dollars a year }\end{array}$ \\
\hline Australia & University of Sidney & $\begin{array}{c}\text { Business and management } \\
\text { Engineering (mechanics) } \\
\text { Philosophy }\end{array}$ & $\begin{array}{l}18383 \\
20164 \\
16204\end{array}$ \\
\hline Great Britain & Oxford University & $\begin{array}{c}\text { Business and management } \\
\text { Engineering (mechanics) } \\
\text { Philosophy }\end{array}$ & $\begin{array}{l}21653 \\
24748 \\
21646\end{array}$ \\
\hline Canada & Laval University & $\begin{array}{c}\text { Business and management } \\
\text { Engineering (mechanics) } \\
\text { Philosophy }\end{array}$ & $\begin{array}{l}10634 \\
11852 \\
11852 \\
\end{array}$ \\
\hline China & Shanghai Jiaotong University & All the bachelor's programs & 3300 \\
\hline Malaysia & University of Malaya & $\begin{array}{c}\text { Business and management } \\
\text { Engineering (mechanics) } \\
\text { Philosophy }\end{array}$ & $\begin{array}{l}1704 \\
1464 \\
1656 \\
\end{array}$ \\
\hline New Zealand & University of Otago & $\begin{array}{c}\text { Business and management } \\
\text { Engineering (mechanics) } \\
\text { Philosophy }\end{array}$ & $\begin{array}{l}12120 \\
13687 \\
11050\end{array}$ \\
\hline Singapore & $\begin{array}{l}\text { National University of } \\
\text { Singapore }\end{array}$ & $\begin{array}{c}\text { Business and management } \\
\text { Engineering (mechanics) } \\
\text { Philosophy }\end{array}$ & $\begin{array}{l}12120 \\
13687 \\
11050\end{array}$ \\
\hline USA & Harvard University & All the bachelor's programs & 31456 \\
\hline Russia & $\begin{array}{c}\text { National Research University } \\
\text { Moscow Power Engineering } \\
\text { Institute }\end{array}$ & $\begin{array}{l}\text { Business and management } \\
\text { Engineering (mechanics) }\end{array}$ & $\begin{array}{l}2400 \\
3000\end{array}$ \\
\hline Japan & University of Tokio & All the bachelor's programs & 4652 \\
\hline
\end{tabular}

Source: Own results

Export of educational services as a driver of the development of an innovative educational environment at the university has a significant impact on improving the basic educational activities, increasing the efficiency of research work, improving the skills of scientific and educational staff, developing the general infrastructure of the university, including the administrative management system (Chernykh \& Parshikov, 2016). The improvement of the basic educational activity is understood as the order and procedures of the educational process, including the elements of the continuity of education or retraining of teachers. The improvement of educational activities through the export of educational services involves the development of educational technologies and the strengthening of the material and technical base of the university. The main objective of the administrative management system is to improve the educational and scientific level of the university through the adaptation of the management system to ever-changing conditions of the external and internal environment both at home and internationally. 
In general, the expansion of export of educational services enables to increase such performance indicators of the university as the number of international agreements and contacts, the number of foreign students, the share of foreign masters, postgraduates and doctoral students, as well as to form a profitable part of the university through the export of knowledge (Rodionov, Fersman, \& Kushneva, 2016). These performance indicators of Russian universities are considered by the specialized federal executive authorities as the basis for supporting the development of the university's innovative educational environment by the state.

\section{CONCLUSIONS}

Despite the need to create and develop an innovative educational environment at Russian universities, the process of introducing modern educational technologies is rather slow. This is due to the stiffness of the applicable educational standards of training, high transaction costs for the development and harmonization of curricula and programs, the prevailing unpreparedness of training personnel to work under the requirements for the training process of the global economy, the weak development of information educational systems and resources.

Another important problem of Russian universities is the lack of a unified system of dissemination of modern educational technologies in educational and research units, approaches to management and quantitative evaluation of the efficiency of this process.

The export of educational services may be a key factor in the formation and development of an innovative educational environment at Russian universities. This will be facilitated by the following circumstances:

- Despite the development of communications and information technologies, the main way of "transferring" educational services remains the movement of students and teachers, which can alleviate the current weak development of information systems of Russian universities and provide the necessary time and resources to prepare the information infrastructure for the wider dissemination of remote (distance) forms of learning.

- Relatively low cost of education while respecting the quality of educational services. Russian education remains one of the leading educational systems among the countries of the Eurasian Economic Union, the Shanghai Cooperation Organization and the Asia-Pacific Region.

The formation of an innovative educational environment by Russian universities will help increase their level of competitiveness on the global market for educational services, provide financial stability, introduce new standards of quality of the educational process and increase the efficiency of research work.

\section{REFERENCES}

Abrhám, J., Bilan, Y., Krauchenia, A., \& Strielkowski, W. (2015). Planning horizon in labour supply of Belarusian small entrepreneurs. Economic Research-Ekonomska Istrą̌ivanja, 28(1), 773-787. doi: https://doi.org/10.1080/1331677X.2015.1084238

Balitskiy, S., Bilan, Y., \& Strielkowski, W. (2014). Energy security and economic growth in the European Union. Journal of Security \& Sustainability Issues, 4(2), 125-132. doi: https://doi.org/10.9770/jssi.2014.4.2(2)

Blanchard, E. J., \& Olney, W. W. (2017). Globalization and human capital investment: Export composition drives educational attainment. Journal of International Economics, 106, 165-183. doi: https://doi.org/10.1016/j.jinteco.2017.03.004

Chernykh, S. I., \& Parshikov, V. I. (2016). Innovative education in Russia. International Journal of Economics and Financial Issues, 6(1S), 239-242. 
Č́abelková, I., \& Strielkowski, W. (2013). Is the level of taxation a product of culture? A cultural economics approach. Society and Economy, 35(4), 513-529. doi: https://doi.org/10.1556/SocEc.2013.0007

Ehrenberger, M., Koudelkova, P., \& Strielkowski, W. (2015). Factors influencing innovation in small and medium enterprises in the Czech Republic. Periodica Polytechnica. Social and Management Sciences, 23(2), 73-83. doi: https://doi.org/10.3311/ppso.7737

Gardelle, L., Cardona Gil, E., Benguerna, M., Bolat, A., \& Naran, B. (2017). The spread of European models of engineering education: The challenges faced in emerging countries. European Journal of Engineering Education, 42(2), 203-218. doi: https://doi.org/10.1080/03043797.2016.1241983

Gurban, I. A., \& Tarasyev, A. A., Jr. (2016). Global trends in education: Russia case study. IF AC-PapersOnLine, 49(6), 186-193.

Healey, N. M. (2017). Beyond 'export education': Aspiring to put students at the heart of a university's internationalisation strategy. Perspectives: Policy and Practice in Higher Education, 1-10.

Ivanova, N., \& Popova, E. (2017). Professionals and the problem of implementing innovation in university. Voprosy Obrazovaniya, 2017(1), 184-206.

Koudelková, P., Strielkowski, W., \& Hejlová, D. (2015). Corruption and System Change in the Czech Republic: Firmlevel Evidence. DANUBE: Law and Economics Review, 6(1), 25-46. doi: https://doi.org/10.1515/danb-2015-0002

Lytvyn, V., Vysotska, V., Chyrun, L., \& Chyrun, L. (2016). Distance learning method for modern youth promotion and involvement in independent scientific researches. Paper presented at the Proceedings of the 2016 IEEE 1st International Conference on Data Stream Mining and Processing, DSMP 2016, 269-274.

Kupriyanov, R. V., \& Gorodetskaya, I. M. (2015). Global trends in higher education and their impact on engineering training in Russia. Paper presented at the Proceedings of 2015 International Conference on Interactive Collaborative Learning ICL 2015, 244-250.

Noskova, T. N., Pavlova, T. B., \& Yakovleva, O. V. (2016). Analysis of domestic and international approaches to the advanced educational practices in the electronic network environment. Integration of Education, 20(4), 456-467. doi: https://doi.org/10.15507/1991-9468.085.020.201604.456-467

Pukhova, M. M., Gruzina, Y. M., \& Kharchilava, K. P. (2016). The role of universities innovation infrastructure in the region development in the Russian Federation. Indian Journal of Science and Technology, 42(9), 1-9. doi: https://doi.org/10.17485/ijst/2016/v9i42/104282

Rodionov, D. G., Fersman, N. G., \& Kushneva, O. A. (2016). Russian universities: Towards ambitious goals. International Journal of Environmental and Science Education, 11(8), 2207-2222.

Shakirova, A. A., \& Valeeva, R. A. (2016). Periods of academic mobility development in Russia. Mathematics Education, 11(6), 1643-1649.

Shvetsova, O. A. (2016). International activity of Russian universities. Case study of St.-Petersburg Electrotechnical University 'LETI'. Paperpresented at the 2016 IEEE Conference on Quality Management, Transport and Information Security, Information Technologies, IT and MQ and IS 2016, 207-210.

Sosnovskaya, G. I., \& Nalimova, I. S. (2016). Innovations in the system of higher education in Russia. Journal of Organizational Culture, Communications and Conflict, 20 (Special Issue), 51-55.

Stukalova, I., Shishkin, A., \& Stukalova, A. (2015). Internationalization of higher education: A case of Russian universities. Economics and Sociology, 8(1), 275-286. doi: bttps:/ / doi.org/10.14254/2071-789X.2015/8-1/21

Voroshilova, A. A. (2015). Academic mobility as a key factor of quality assurance in tertiary education. Paperpresented at the IOP Conference Series: Materials Science and Engineering. 